\title{
The role of NPY in expression and extinction of conditioned fear Dilip Verma ${ }^{1}$, Ramon O Tasan*1, Herbert Herzog ${ }^{2}$ and Günther Sperk ${ }^{1}$
}

Address: ${ }^{1}$ Institute of Pharmacology, Innsbruck Medical University, 6020 Innsbruck, Austria and ${ }^{2}$ Research Program, Garvan Institute of Medical Research, Sydney, NSW 2010, Australia

Email: Ramon O Tasan* - ramon.tasan@i-med.ac.at

* Corresponding author

from I5th Scientific Symposium of the Austrian Pharmacological Society (APHAR) Joint meeting with the Hungarian Society of Experimental and Clinical Pharmacology (MFT) and the Slovenian Pharmacological Society (SDF)

Graz, Austria. 19-2I November 2009

Published: 12 November 2009

BMC Pharmacology 2009, 9(Suppl 2):A33 doi:10.1 186/147I-2210-9-S2-A33

This abstract is available from: http://www.biomedcentral.com/I47I-22I0/9/S2/A33

(C) 2009 Verma et al; licensee BioMed Central Ltd.

\section{Background}

Neuropeptide $\mathrm{Y}$ is a highly conserved 36 amino acid peptide that is widely distributed in the peripheral and central nervous systems. Besides its functions in various metabolic processes, NPY has attracted considerable attention in modulating emotional-affective behavior. NPY exerts a solid anxiolytic effect most likely mediated by $\mathrm{Y}_{1}$ receptors, whereas stimulation of predominantly pre-synaptic $\mathrm{Y}_{2}$ receptors results in increased anxiety. However, little is known about an involvement of NPY in processing of fear.

\section{Methods}

The current study aims to elucidate the role of NPY in Pavlovian fear conditioning, a simple form of associative learning. NPY knockout (NPY KO) mice as well as knockout mice for the different NPY receptors $\left(\mathrm{Y}_{1}, \mathrm{Y}_{2}, \mathrm{Y}_{4}\right.$ and $\mathrm{Y}_{1} /$ $\mathrm{Y}_{2}$ double $\mathrm{KO}$ ) were subjected to a delay fear-conditioning paradigm (5 presentations of a tone co-terminating with a mild electric foot shock, $0.7 \mathrm{~mA}$ ). Extinction learning was performed the following day by repetitive exposure to the tone (40 presentations) in the absence of a foot shock.

\section{Results}

Compared to wild-type controls, NPY KO mice revealed faster acquisition and augmented expression of conditioned fear. Baseline freezing was increased on retention/ extinction day, indicating a generalization of conditioned fear. Moreover, NPY KO mice displayed a pronounced deficit in the extinction of fear memory. Within sessions, extinction as well as extinction recall were significantly impaired in NPY KO mice. Conversely, acquisition of fear was reduced in $\mathrm{Y}_{2} \mathrm{KO}$ mice. Interestingly, no corresponding changes in extinction of conditioned fear were seen in $\mathrm{Y}_{2} \mathrm{KO}$ mice. However, $\mathrm{Y}_{4} \mathrm{KO}$ mice exhibited an impairment in fear extinction, similar to the one seen in NPY KO mice.

\section{Conclusion}

Our data indicate that NPY has a protective role in the acquisition of fear memories. In addition, it facilitates extinction of conditioned fear. Results from $\mathrm{Y}$ receptor $\mathrm{KO}$ mice suggest that $Y_{1}$ and $Y_{2}$ receptors are the most likely candidates for modulating the acquisition of fear, whereas for extinction a concerted action of $\mathrm{Y}_{1}$ and $\mathrm{Y}_{4}$ receptors seems to be conceivable. 